\title{
New records of diatoms for the algal flora of Ukraine from water bodies of Nyzhniosulsky National Nature Park
}

\author{
Olha M. KRYVOSHEIA ${ }^{1}$, Dmytro O. KAPUSTIN ${ }^{2}$ \\ ${ }^{1}$ M.G. Kholodny Institute of Botany, NAS of Ukraine \\ 2 Tereschenkivska Str., Kyiv 01004, Ukraine \\ olha_krivosheia@ukr.net \\ ${ }^{2}$ Papanin Institute for Biology of Inland Waters RAS \\ Settle of Borok, Yaroslavl Region 152742, Russia \\ dima_kapustin@outlook.com
}

Kryvosheia O.M., Kapustin D.O.2019. New records of diatoms for the algal flora of Ukraine from water bodies of Nyzhniosulsky National Nature Park. Ukrainian Botanical Journal, 76(6): 554-559.

Abstract. Here we present new records of diatoms for the algal flora of Ukraine from water bodies of Nyzhnosulsky National Nature Park. The following species are recorded for the first time in Ukraine: Achnanthidium eutrophilum, Caloneis biconstrictoides, Encyonema lacustre, Gomphonema angusticephalum, Karayevia kolbei, K. suchlandtii, Placoneis abiskoensis, P. paraelginensis, Stauroneis balatonis, and Tryblionella salinarum. Some of them are rare and noteworthy taxa. For Caloneis biconstrictoides, it is the third known record in the world; Placoneis abiskoensis is a rare Holarctic species. The reported records of the new, rare and interesting taxa in the investigated water bodies may indicate a high nature conservation significance of Nyzhniosulsky National Nature Park as an algal reserve. The taxonomic position, synonymy, morphological features, information about ecology, distribution and original photomicrographs are provided.

Keywords: diatoms, new floristic records, Nyzhniosulsky National Nature Park, Poltava Plain Algofloristic District

Submitted 21 November 2018. Published 29 Desember 2019

Кривошея О.М. ${ }^{1}$, Капустін Д.О. ${ }^{2}$ 2019. Нові знахідки діатомових водоростей для альгофлори України 3 водойм Національного природного парку "Нижньосульський". Украӥнський ботанічний журнал, 76(6): 554-559.

${ }^{1}$ Інститут ботаніки ім. М.Г. Холодного НАН України

вул. Терещенківська 2, Київ 01004, Україна

${ }^{2}$ Інститут біології внутрішніх вод ім. І.Д. Папаніна РАН

сел. Борок, Ярославська обл. 152742, Росія

Реферат. У статті представлені дані щодо нових та цікавих видів діатомових водоростей флори України з водойм Національного природного парку "Нижньосульський". Види Achnanthidium eutrophilum, Caloneis biconstrictoides, Encyonema lacustre, Gomphonema angusticephalum, Karayevia kolbei, K. suchlandtii, Placoneis abiskoensis, P. paraelginensis, Stauroneis balatonis, Tryblionella salinarum є новими знахідками для флори України. Серед них є рідкісні та цікаві таксони. Для Caloneis biconstrictoides це третє місцезнаходження у світі, Placoneis abiskoensis є рідкісним голарктичним видом. Наявність нових, рідкісних та цікавих таксонів у досліджених водоймах засвідчує високе значення Національного природного парку "Нижньосульський" як альгорезервату зазначених видів. У статті наведено відомості про систематичне положення, синоніми, морфологічні характеристики, екологію і поширення виявлених видів та їхні оригінальні мікрофотографії.

Ключові слова: діатомові водорості, нові види, Нижньосульський національний природний парк, Полтавськорівнинний альгофлористичний район

\section{Introduction}

Although diatoms in Ukraine have been studied for more than 150 years, considerable territories of Ukraine remain poorly investigated until now. This is the case especially for the Left-Bank Forest-Steppe of Ukraine where, according to the literature data, only 350 species of diatoms have been reported (Algae of
Ukraine..., 2009). In particular, one of the interesting areas in this respect is Nyzhniosulsky National Nature Park (NSNNP), located in the lower reaches of the Sula River in Poltava and Cherkasy regions. According to the algofloristic zoning of Ukraine, this territory belongs to the Poltava Plain Algofloristic District (PalamarMordvintseva, Tsarenko, 2015). A complex of various

(C) 2019 O.M. Kryvosheia, D.O. Kapustin. Published by the M.G. Kholodny Institute of Botany, NAS of Ukraine. This is an open access article under the terms of the Creative Commons Attribution License (http://creativecommons.org/licenses/by/4.0/), which permits use, distribution, and reproduction in any medium, provided the original work is properly cited 
types of water bodies with different hydrological and hydrochemical parameters are presented in NSNNP (Nyzhniosulsky..., 2018). However, until now, data on the algal flora of the park were limited and did not represent the actual diversity of the diatom flora of this territory (Kryvosheia, Kapustin, 2019).

During the study of diatoms of NSNNP we revealed 284 species (285 infraspecies taxa, incl. typical ones) (Kryvosheia, Kapustin, 2019), including a number of new and interesting species for the flora of Ukraine which are presented in this article.

\section{Materials and methods}

Periphyton, plankton and benthos samples (38) from various types of water bodies of Nyzhniosulsky National Nature Park (N49 36'28', E33 $\left.11^{\prime} 27^{\prime \prime}\right)$ were collected during different seasons in 2016-2017. Samples were fixed by $4 \%$ formaldehyde for later storage in the National Herbarium of Ukraine (KW-A). For diatom research, the samples were treated according to a standard technique using concentrated $35 \% \mathrm{H}_{2} \mathrm{O}_{2}$ (Prygiel, Coste, 2000). The obtained frustules were mounted in Naphrax ${ }^{\circledR}$ (refractive index 1.74) (Fleming, Roy, 1943). In addition, this material was used for scanning electron microscopy (SEM). Permanent slides were studied using light microscopes MBI-6 with phase contrast (LOMO, Russia), Olympus BX-53 (Olympus, Japan) and a scanning electron microscope JEM-1230 (JEOL, Japan) at the Center for the Collective Use of Electron Microscopes NASU.

Diatoms were identified using issues of Süßwasserflora von Mitteleuropa (Krammer, 1986, 1991; Krammer, Lange-Bertalot, 1989), other taxonomic treatments (Krammer, 1997; Reichardt, 1999; LangeBertalot et al., 2011, 2017; Bąk et al., 2012; Bey, Ector, 2013a-d; Kulikovskiy et al., 2016), articles and electronic sources (Cox, 2003; Levkov et al., 2007; Levkov, Williams, 2014; Kulikovskiy et al., 2015, 2016; Diatoms of North America..., 2018).

In the article we followed the system of Medlin and Kaczmarska (2004) accepted in the series Algae of Ukraine...(2009), with some updates (Kulikovskiy et al., 2016).

\section{Results and discussion}

Ten species are newly reported for Ukraine. Their taxonomic position, synonymy, morphological features, information about ecology, distribution and original photomicrographs are given below.

\section{Class Bacillariophyceae}

Subclass Bacillariophycidae

Order Cymbellales D.G.Mann

Family Cymbellaceae Greville

Encyonema lacustre (C.Agardh) Pantocsek (Fig. 1, A) $(=$ Schizonema lacustre C.Agardh, Colletonema lacustre (C.Agardh) Kütz., Cymbella lacustris (C.Agardh) Cleve, Navicula lacustris (C.Agardh) Schütt).

Valves semi-lanceolate and dorsiventral. Valve apices broadly rounded. Valve length $54.04 \mu \mathrm{m}$, valve width $12.49 \mu \mathrm{m}, \mathrm{L} / \mathrm{W}$ 4.3. Axial area narrow, central area small, circular. Proximal raphe ends curve slightly to the dorsal margin. Striae radiate at the valve center and become parallel, or even convergent, near the valve apices, 11 in $10 \mu \mathrm{m}$.

Ecology. This species occurs in calcium-rich, oligo- to eutrophic water bodies with elevated levels of electrolytes, $\beta$ - $\alpha$-mesosaprobe (Lange-Bertalot et al., 2011).

Locality. Benthos, the Orzhytsia River, urban-type settlement of Orzhytsia, Orzhytsia District, Poltava Region, NSNNP, August, $2016\left(t 26^{\circ} \mathrm{C}, \mathrm{pH}\right.$ 8.6).

Distribution. Widely distributed in Europe, North and South America, Asia (AlgaeBase..., 2019).

Placoneis abiskoensis (Hust.) Lange-Bert. \& Metzeltin (Fig. 1, D)

(= Navicula abiskoensis Hust., $N$. dicephala $\mathrm{f}$. abiskoensis (Hust.) A.Cleve, N. dicephala f. abiskoensis (Hust.) Hust.)

Valves linear, with weakly concave margins. Valve margins triundulate in the largest specimens. Apices sub-capitate. Valve length $43.85-47.76 \mu \mathrm{m}$, valve width $10.42-10.77 \mu \mathrm{m}$. Axial area very narrow and widens slightly as it approaches a transversely rectangular central area. Striae strongly curved and radiate except at the ends, where they straight and parallel, 9-10 in $10 \mu \mathrm{m}$.

Ecology. This species seems to be a northern one, in oligotrophic to mesotrophic lakes (Cox, 2003).

Locality. Plankton, the Sula River, Tarasivka village, Orzhytsia District, Poltava Region, NSNNP, August, $2016\left(t 24^{\circ} \mathrm{C}, \mathrm{pH}\right.$ 8.6) and May, $2017\left(t 15^{\circ} \mathrm{C}, \mathrm{pH} 8.3\right)$.

Distribution. Rare Holarctic species (Kulikovskiy et al., 2016).

Note. According to E. Cox (2003), valves of this species have a length of $36-46 \mu \mathrm{m}$, while we found specimens with longer valves. 

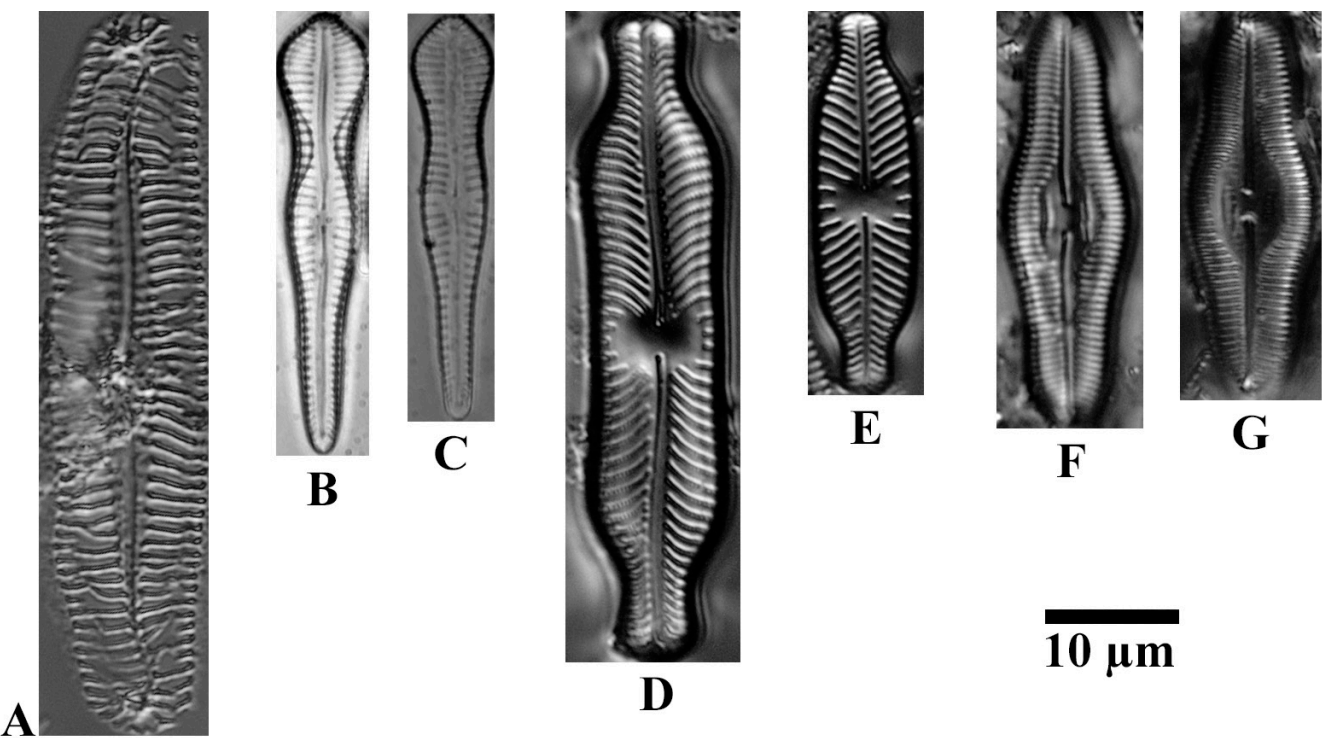

G
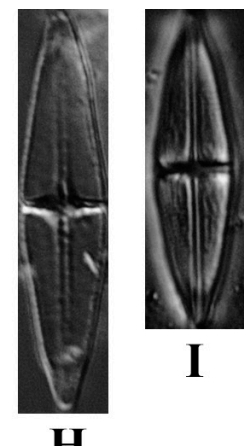

A
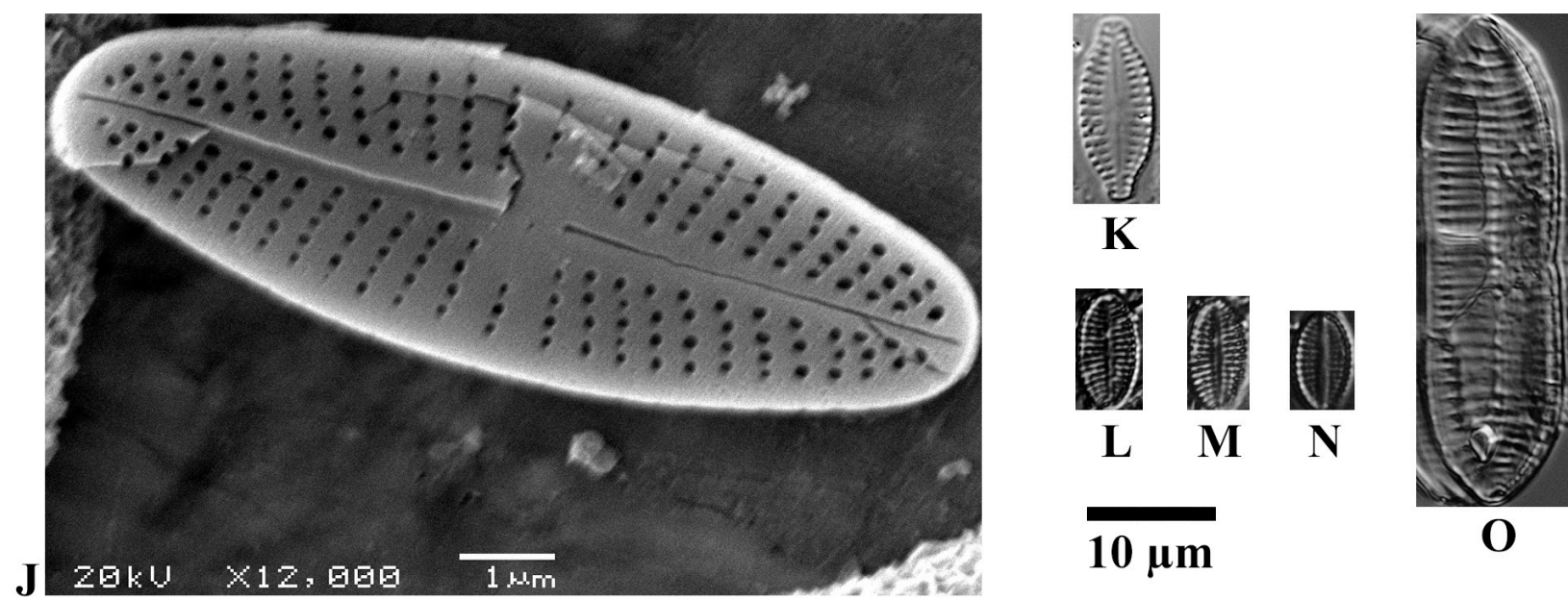

Fig. 1. New for Ukraine records of diatom species from Nyzhnosulsky National Nature Park

A: Encyonema lacustre; B, C: Gomphonema angusticephalum; D: Placoneis abiskoensis; E: P. paraelginensis; F, G: Caloneis biconstrictoides; H, I: Stauroneis balatonis; J: Achnanthidium eutrophilum; K: Karayevia kolbei; L-N: K. suchlandtii; O: Tryblionella salinarum

Placoneis paraelginensis Lange-Bert. (Fig. 1, E)

Valves linear, with somewhat convex margins. Apices subcapitate. Valve length $28.28 \mu \mathrm{m}$, valve width $7.74 \mu \mathrm{m}, \mathrm{L} / \mathrm{W}$ 3.7. Axial area very narrow and linear. Central area transversely rectangular, occupies more than $1 / 2$ valve width. Striae radiate throughout the valve, slightly wider apart at the centre of the valve, and shorter in the central area, 12 in $10 \mu \mathrm{m}$.

Ecology. Recent and fossil freshwater (Cox, 2003), occurs in waters with high level of mineralization and low level of organic matter (Bey, Ector, 2013b).
Locality. Benthos, the Sula River, Maloseletske village, Orzhytsia District, Poltava Region, NSNNP, November 2016 ( $\left.t 4{ }^{\circ} \mathrm{C}, \mathrm{pH} 7\right)$.

Distribution. Widely distributed in Europe, North and South America, Asia (AlgaeBase..., 2019).

\section{Family Gomphonemataceae Kütz.}

Gomphonema angusticephalum E. Reichardt \&LangeBert. (Fig. 1, B, C)

Valves heteropolar, broadest near the headpole but tumid at the center of the valve. Valve length 30.12 $32.67 \mu \mathrm{m}$, valve width in the middle $4.62-5.13 \mu \mathrm{m}$, in 
the headpole 5.53-6.17 $\mu \mathrm{m}$. Axial area narrow, central area small, rounded with one stigma. Striae parallel, in the middle and on the ends of valves weakly radial, $12-14$ in $10 \mu \mathrm{m}$.

Ecology. Freshwater species, sensitive to pollution (Bey, Ector, 2013).

Locality. Periphyton, Drachkove Lake, Horoshyno village, Orzhytsia District, Poltava Region, NSNNP, August $2016\left(t 26^{\circ} \mathrm{C}, \mathrm{pH} 7.7\right)$.

Distribution. France, Netherlands, USA (AlgaeBase..., 2019), Russia (Kulikovskiy et al., 2015).

Family Achnanthales P.C.Siva

Родина Achnanthidiaceae D.G.Mann

Achnanthidium eutrophilum (Lange-Bert.) Lange-

Bert. (Fig. 1, J)

(= Achnanthes eutrophila Lange-Bert.)

Valve linear-elliptic with broadly rounded, nonprotracted apices. Valve length $9.69 \mu \mathrm{m}$, valve width $3.19 \mu \mathrm{m}$. Axial area narrow and linear gradually expanding toward the valve center, central area weakly developed. Striae radiate becoming denser and more strongly radiate toward the apices, 30 in $10 \mu \mathrm{m}$. Striae composed of 4-5 rounded areolae.

Ecology. Eutrophic to polyeutrophic running waters (Lange-Bertalot et al., 2017).

Locality. Plankton, the Sula River, Tarasivka village, Orzhytsia District, Poltava Region, NSNNP, February $2017\left(t 0{ }^{\circ} \mathrm{C}, \mathrm{pH} 7\right)$.

Distribution. Widely distributed in Europe; the most abundant species after Achnanthidium minutissimum s. str. (Lange-Bertalot et al., 2017).

Note. Probably this species is more widely distributed in Ukraine but often erroneously identified as Achnanthidium minutissimum s. 1 .

\section{Order Naviculales Bessey sensu Round, Crawford \& D.G.Mann}

\section{Family Pinnulariaceae D.G.Mann}

Caloneis biconstrictoides Levkov (Fig. 1, F, G)

Valves broadly lanceolate, gibbous in the middle, with rounded and not protracted apices. Valve length $28.46-30.78 \mu \mathrm{m}$, valve width $9.23-10.0 \mu \mathrm{m}$. Axial area narrow, widened near the central area. Central area wide round, with large lunate thickened macula on both sides of proximal raphe endings. Raphe distinctly lateral with central pores deflected unilaterally. Striae weakly radiate, 20 in $10 \mu \mathrm{m}$.

Ecology. Oligotraphentic species, which prefers slightly alkaline waters (Levkov et al., 2007).
Locality. Plankton and benthos, the Sula River, Maloseletske village, Orzhytsia District, Poltava Region, NNPNS, August $2016\left(t 24^{\circ} \mathrm{C}, \mathrm{pH} 8\right)$ and 2017 $\left(t 24^{\circ} \mathrm{C}, \mathrm{pH} 7.6\right)$.

Distribution. North Macedonia (Levkov et al., 2007; Levkov, Williams, 2014), Russia (Kulikovskiy et al., 2016).

Note. With respect to its valve shape, it resembles Caloneis silicula var. tumida Hust. differing from the latter mainly by the presence of macula on the central area. Caloneis schumanniana var. biconstricta (Grunow) Reichelt differs in the valve shape with distinctly triundulated valve margins and strongly protracted and cuneate apices.

\section{Family Stauroneidaceae D.G.Mann ${ }^{1}$}

Karayevia kolbei (Hust.) Bukht. (Fig. 1, K)

(= Achnanthes kolbei Hust., Kolbesia kolbei (Hust.)

Round \& Bukht. nom. illeg.)

Valves elliptical-lanceolate. Apices short, rostrate. Valve length $14.31 \mu \mathrm{m}$, valve width $5.82 \mu \mathrm{m}$. Axial area narrow lanceolate, distinct central area lacking. Striae radiate and interrupted by a marginal longitudinal line, 13 in $10 \mu \mathrm{m}$.

Ecology. Unlike $K$. ploenensis, this species occurs mainly in alkaline, $\beta$-mesosaprobic rivers (LangeBertalot et al., 2011).

Locality. Benthos, the Sula River, Maloseletske village, Orzhytsia District, Poltava Region, NSNNP, August 2017 ( $\left.t 24^{\circ} \mathrm{C}, \mathrm{pH} 5,1\right)$.

Distribution. Widely distributed in Europe, North America and Asia (AlgaeBase..., 2019).

Note. The valves shape of this species is similar to that in K. ploenensis (Hust.) Bukht., but striae of the latter species are not interrupted by a marginal longitudinal line (LangeBertalot et al., 2011).

Karayevia suchlandtii (Hust.) Bukht. (Fig. 1, L, M, N)

(= Achnanthes suchlandtii Hust., A. lewisiana R.M.Patrick, Cocconeis utermoehlii Hust., A. suchlandtii var. robusta Hust., Kolbesia suchlandtii (Hust.) J.C.Kingston).

Valves linear-elliptical. Valve length 7.3-9.2 $\mu \mathrm{m}$, valve width $3.89-4.37 \mu \mathrm{m}$. Axial area lanceolate. Central area indistinct. Striae in the middle of the valves almost parallel, becoming radiate toward apices, 18-20 in $10 \mu \mathrm{m}$.

Ecology. Occurs in oligotrophic waters; an indicator of good water quality (Lange-Bertalot et al., 2011).

${ }^{1}$ Genus Karayevia is included in a clade together with stauroneoid diatom genera such as Stauroneis, Prestauroneis, Craticula (Kulikovskiy et al., 2019). 
Locality. Plankton and benthos, the Sula River, Maloseletske village, Orzhytsia District, Poltava Region, NSNNP, May $2017\left(t 14^{\circ} \mathrm{C}, \mathrm{pH} 8,5\right)$.

Distribution. Widely distributed in Europe, North and South America, Asia, Australia and New Zealand (AlgaeBase..., 2019).

Stauroneis balatonis Pantocsek (Fig. 1, H, I)

Valves lanceolate, rhombic-lanceolate with short, slightly protracted apices. Valve length $23.81-29.57 \mu \mathrm{m}$, valve width $5.77-6.52 \mu \mathrm{m}$. Axial area very narrow, slightly widened towards valve central area. Central area with distinct stauros, narrow, not expanded towards valve margins. Raphe fissures almost straight, filiform. Transapical striae fine, indistinctly punctate, parallel to weakly radiate, low-observable in LM.

Ecology. Freshwater species (AlgaeBase..., 2019).

Locality. Plankton and periphyton, the Sula River, Maloseletske village, Orzhytsia District, Poltava Region, NSNNP, August 2017 ( $t 24^{\circ} \mathrm{C}, \mathrm{pH}$ 7.6).

Distribution. This species was recorded only in lakes Ohrid and Prespa (North Macedonia), where it occurs in sediments from various water depths; it has a broad distribution in Europe as a fossil (under the name S. smithii var. incisa Pantocsek) (Levkov et al., 2016).

\section{Order Bacillariales Hendey}

Family Bacillariaceae Ehrenb.

Tryblionella salinarum (Grunow) Pantoscek (рис. 1, O)

(= Nitzschia salinarum Grunow, $N$. calida var. salinarum (Grunow) Frenguelli, $N$. levidensis var. salinarum (Grunow) Krammer \& Lange-Bert.)

Valves broadly lanceolate, slightly concave in the middle of the valve. Apices drawn out and narrowly rounded. Valve length $37.72 \mu \mathrm{m}$, valve width $10.76 \mu \mathrm{m}$. Keel strongly excentric, with the central nodule formed by two fibulae. Fibulae 9 in $10 \mu \mathrm{m}$. Transapical ribs distinct, 12 in $10 \mu \mathrm{m}$. Striae indistinct in LM.

Ecology. This species occurs in salt-water of sea coast, brackish-water of river mouth and also in continental waters with high content of electrolytes, $\alpha$-mesosaprobe (Lange-Bertalot et al., 2011).

Locality. Periphyton, the Sula River, Maloseletske village, Orzhytsia District, Poltava Region, NSNNP, November $2016\left(t 4{ }^{\circ} \mathrm{C}, \mathrm{pH} 7\right)$.

Distribution. Widely distributed in Europe and Asia (AlgaeBase..., 2019).

Remark. The valves shape of this species is similar to that of $T$. levidensis W.Smith and T. calida (Grunow) D.G.Mann. However, T. levidensis has a smaller number of support ribs $(7-10$ in $10 \mu \mathrm{m})$ and $T$. calida has pronounced rostrate apices (LangeBertalot et al., 2011).

\section{Conclusions}

Ten species of diatoms were recorded for the first time in Ukraine. It is very likely that some of them have been previously found but not distinguished from the similar species. For instance, Gomphonema angusticephalum and Achnanthidium eutrophilum were formerly lumped under Gomphonema acuminatum Ehrenb. (Reichardt, 1999; Kulikovskiy et al., 2015) and Achnanthidium minutissimum (Kütz.) Czarn. (Lange-Bertalot, Metzeltin, 1996), respectively, and only recently were recognized as separate species.

Other species (e.g. Encyonema lacustre, Placoneis paraelginensis, Karayevia kolbei, K. suchlandtii, Tryblionella salinarum) are widely distributed but they have not been previously recorded in Ukraine due to the lack of detailed investigations. It should be noted that the record of T. salinarum, a species that prefers brackish waters, in the Sula River indicates the high electrolyte content of its waters. This conclusion is confirmed by hydrochemical analysis (Aqualandscape..., 2014).

Moreover, we have recorded several rare diatom species, such as Placoneis abiskoensis and Caloneis biconstrictoides. Stauroneis balatonis has a few extant records from lakes Ochrid and Prespa in North Macedonia (Levkov et al., 2016) but it is widely distributed in Europe and Asia as a fossil, known under the name $S$. smithii var. incisa Pantocsek.

Generally, the presence of the new, rare and interesting taxa in the water bodies of Nyzhniosulsky NNP may indicate its high nature conservation significance as an algal reserve.

\section{REFERENCES}

Algae of Ukraine: Diversity, Nomenclature, Taxonomy, Ecology and Geography, vol. 2. Bacillariophyta. 2009. Eds P.M. Tsarenko, S.P. Wasser, E. Nevo. Ruggel: A.R.G. Gantner Verlag K.-G., 413 pp.

AlgaeBase. World-wide electronic publication, National University of Ireland. 2019. Available at: http://www. algaebase.org (Accessed 03 May 2019).

Aqualandscape and biological diversity of the Nyzhniosulskyi National Natural Park, Ukraine. 2014. Ed. V.I. Shcherbak. Kiev: Phytosociocentre, 266 pp. [Акваландшафтное u биологическое разнообразие Национального природного парка "Нижнесульский", Украина. 2014. Ред. В.И. Щербак. Киев: Фитосоциоцентр, 266 с.].

Bąk M., Witkowski A., Zelazna-Wieczorek J., Wojtal A.Z., Szczepocka E., Szulc A., Szulc B. 2012. Klucz do oznaczania okrzemek $w$ fitobentosie na potrzeby oceny stanu ekologicznego wód powierzchniowych w Polsce. Warszawa [Warsaw]: Glowny Inspektorat Ochrony Srodowisk, $452 \mathrm{~s}$. 
Bey M.-Y., Ector L. 2013a. Atlas des diatomées des cours d'eau de la region Rhône-Alpes: Naviculacées (Naviculoidées: Adlafia, Amphipleura, Aneumastus, Anomoeoneis, Berkeleya, Brachysira, Caloneis, Cavinula, Chamaepinnularia, Craticula, Diadesmis, Didymosphenia, Diploneis, Eolimna, Fallacia, Fistulifera, Frustulia, Geissleria, Gyrosigma, Hippodonta, Kobayasiella, Luticola, Mayamaea, Naviculadicta, Neidiomorpha, Neidium, Nupela, Oestrupia, Parlibellus), vol. 3. Luxembourg: CRP-GL, 196 pp.

Bey M.-Y., Ector L. 2013b. Atlas des diatomées des cours d'eau de la region Rhône-Alpes: Naviculacées (Naviculoidées: Navicula, Pinnularia, Placoneis, Prestauroneis, Pulchella, Sellaphora, Stauroneis), vol. 4. Luxembourg: CRP-GL, 217 pp.

Bey M.-Y., Ector L. 2013c. Atlas des diatomées des cours d'eau de la region Rhône-Alpes: Naviculacées: Cymbelloidées, Gomphonématoidées, vol. 5. Luxembourg: CRP-GL, 217 pp.

Bey M.-Y., Ector L. 2013d. Atlas des diatomées des cours d'eau de la region Rhône-Alpes: Bacillariacées, Rhopalodiacées, Surirellacées, vol. 6. Luxembourg: CRP-GL, 206 pp.

Cox E.J. 2003. Placoneis Mereschkowsky (Bacillariophyta) revisited: resolution of several typification and nomenclatural problems, including the generitype. Botanical Journal of the Linnean Society, 141(1): 53-83.

Diatoms of North America. The source for diatom identification and ecology. 2018. Available at: https://diatoms.org (Accessed 14 October 2018).

Fleming W., Roy J. 1943. A high index mounting medium for microscopy. Microscopical Society, 63: 34-37.

Krammer K. 1986. Bacillariophyceae 1. Naviculaceae. In: Süßwasserflora von Mitteleuropa. Stuttgart; New York: Gustav Fischer Verlag, 876 S.

Krammer K., Lange-Bertalot H. 1989. Bacillariophyceae 2. Bacillariaceae, Epithemiaceae, Surirellaceae. In: Süßwasserflora von Mitteleuropa. Stuttgart: Gustav Fischer Verlag, $569 \mathrm{~S}$.

Krammer K. 1991. Bacillariophyceae. 4. Achnanthaceae. Kritische Erganzungen zu Navicula (Lineolatae) und Gomphonema. In: Süßwasserflora von Mitteleuropa. Stuttgart: Gustav Fischer Verlag, 437 S.

Krammer K. 1997. Die cymbelloiden Diatomeen. Eine Monographie der weltweit bekannten Taxa. 1. Allegmeins und Encyonema. In: Bibliotheca diatomologica. Berlin; Stuttgart: J. Cramer, 382 pp.

Kryvosheia O., Kapustin D. 2019. Algologia, 29(3): 298-321. [Кривошея О.Н., Капустин Д.О. 2019. Диатомовые водоросли Национального природного парка "Нижнесульский" (Украина). Альгологія, 29(3): 298-321]. https://doi.org/10.15407/alg29.03.298

Kulikovskiy M.S., Kociolek J.P., Solak C.N., Kuznetsova I. 2015. The diatom genus Gomphonema Ehrenberg in Lake Baikal. II. Revision of taxa from Gomphonema acuminatum and Gomphonema truncatum-capitatum complexes. Phytotaxa, 233(3): 251-272.
Kulikovskiy M.S., Glushchenko A.M., Genkal S.I., Kuznetsova I.V. 2016. Opredelitel diatomovykh vodorosley Rossii (Identification book of diatoms from Russia). Yaroslavl: Filigran, 804 pp. [Куликовский М.С., Глущенко А.М., Генкал С.И., Кузнецова И.В. 2016. Определитель диатомовых водорослей России. Ярославль: Филигрань, 804 с.].

Kulikovskiy M., Maltsev Y., Andreeva S., Glushchenko A., Gusev E., Podunay Y., Ludwig T.V., Tusset E., Kociolek J.P. 2019. Description of a new diatom genus Dorofeyukea gen. nov. with remarks on phylogeny of the family Stauroneidaceae. Journal of Phycology. https://doi. org/10.1111/jpy. 12810

Lange-Bertalot H., Hofmann G., Werum M. 2011. Diatomeen im Süßwasser-Benthos von Mitteleuropa. Ruggel: A.R.G. Gantner Verlag K.-G., 908 S.

Lange-Bertalot H., Hofmann G., Werum M., Cantonati M. 2017. Freshwater benthic diatoms of Central Europe: over 800 common species used in ecological assessment. English edition with updated taxonomy and added species. Eds M. Cantonati, M.G. Kelly, H. Lange-Bertalot. Schmitten-Oberreifenberg: Koeltz Botanical Books, 942 pp.

Lange-Bertalot H., Metzeltin D. 1996. Indicators of Oligotrophy. 800 taxa representative of three ecologically distinct lake types: carbonate buffered - oligodystrophicweakly buffered soft water. Iconographia Diatomologica, 2: $1-390$.

Levkov Z., Kristic S., Metzeltin D., Nakov T. 2007. Diatoms of Lakes Prespa and Ohrid. About 500 taxa from ancient lake system. Iconographia Diatomologica, 16: 1-613.

Levkov Z., Williams D.M. 2014. Observations on Caloneis Cleve (Bacillariophyceae) species from the ancient lakes Ohrid and Prespa. Nova Hedwigia, 143: 141-158. https:// doi.org/10.1127/1438-9134/2014/008

Levkov Z., Tofilovska S., Jovanovska E., Cvetkoska A., Metzeltin D. 2016. Revision of the Stauroneis smithii Grunow (Bacillariophyceae) species complex from Macedonia. Botanica Serbica, 40(2): 167-178. https:// doi.org/10.5281/zenodo.162215

Medlin L.K., Kaczmarska I. 2004. Evolution of the diatoms: V. Morphological and cytological support for the major clades and a taxonomic revision. Phycologia, 43: 245-270.

Nyzhniosulskyi National Natural Park. [Національний природний парк "Нижньосульський"]. Available at: http://nppns.at.ua (Accessed 13 November 2018).

Palamar-Mordvintseva G.M., Tsarenko P.M. 2015. Algofloristic zoning of Ukraine. International Journal on Algae, 25(4): 303-328. https://doi.org/10.1615/ InterJAlgae.v17.i4.10

Prygiel J., Coste M. 2000. Guide méthodologique pour la mise en ouvre de l'Indice Biologique Diatomées. Bordeaux: Agences de l'Eau Cemagref, 134 pp.

Reinchardt E. 1999. Zur revision der Gattung Gomphonema. In: Iconographia Diatomologica, vol. 8. Ruggell: A.R.G. Gantner K.-G., 916 pp.

Рекомендує до друку С.Я. Кондратюк 